\title{
Post-hatch Changes in the Immunoexpression of Desmin, Smooth Muscle Actin and Vimentin in the Testicular Capsule and Interstitial Tissue of the Japanese quail (Coturnix coturnix japonica)
}

\author{
M.-C. Madekurozwa* \\ Address of author: Department of Anatomy and Physiology, University of Pretoria, Private bag X04, Onderstepoort, 0110, South Africa
}

\author{
*Correspondence: \\ Tel: +27 125298417 ; \\ fax: +27125298320 ; \\ e-mail: mary.madekurozwa@up.ac.za
}

With 5 figures and 2 tables

\begin{abstract}
Summary
The post-hatch development of immunoreactivity to desmin, smooth muscle actin (SMA) and vimentin in the testicular capsule and interstitial tissue of day-old to adult quails was described in this study. The tunica albuginea of the testicular capsule was composed mainly of myoid cells. A zonal arrangement of desmin and SMA immunostaining was observed in myoid cells of the tunica albuginea in 1- to 24-day-old quails. Immunostaining for SMA and desmin was uniform in the tunica albuginea of adult birds. Vimentin immunostaining in the testicular capsule was demonstrated in mesothelial cells, endothelial cells and fibroblasts. The interstitial tissue contained mesenchymal cells, peritubular myoid cells, I.eydig cells and fibroblasts. Desmin-immunopositive mesenchymal cells were present in the interstitial tissue of 1- to 17-day-old quails. Peritubular myoid cells expressed strong desmin immunostaining in all developmental stages, while the intensity of SMA immunostaining increased with testicular maturation. Vimentin was demonstrated in Leydig cells and fibroblasts, while the peritubular myoid cells displayed strong vimentin immunostaining only in adult birds. Strong vimentin immunostaining was demonstrated in the endothelial cells of capsular and interstitial blood vessels. The tunica media of these blood vessels displayed desmin and SMA immunostaining. The results of the study have established that variability exists in the distribution and intensity of desmin, SMA and vimentin immunostaining in the testicular capsule and interstitial tissue of the post-hatch Japanese quail.
\end{abstract}

\begin{abstract}
Introduction
Immunohistochemical and electron microscopy techniques have been used to demonstrate smooth muscle or myoid cells in the testicular capsule of mammalian (Hargrove et al., 1977; Chacon-Arellano and Woolley, 1980; Santamaria et al., 1990; Banks et al., 2006) and avian species (Aire and Ozegbe, 2007; Ozegbe et al., 2008, 2012). Myoid cells in the testicular capsules of birds have been shown to contain various cytoskeletal proteins including smooth muscle actin (SMA) (Maretta and Marettova, 2004; Abd-Elmaksoud, 2009; Ozegbe et al., 2012), desmin (Maretta and Marettova, 2004; Ozegbe et al., 2012) and vimentin (Aire and Ozegbe, 2007; Ozegbe et al., 2008).
\end{abstract}

The interstitial tissue of bird's testes is composed of an interstitium and a peritubular boundary tissue (Rothwell and Tingari, 1973; Rothwell, 1975; Aire, 1997). The peritubular boundary tissue corresponds to the lamina propria of the mammalian testis. The interstitium, which is predominantly loose connective tissue, accommodates Leydig cells, fibroblasts, as well as components of the vascular and lymphatic systems (Nicholls and Graham, 1972; Aire, 1997; Madekurozwa et al., 2002). The peritubular boundary tissue, which surrounds the seminiferous tubules, is composed of an inner fibrous layer and an outer cellular layer. The latter is formed by the attenuated cytoplasmic processes of myoid cells, which are also termed myofibroblasts (Aire and Ozegbe, 2007). These 
peritubular myoid cells display morphological and functional characteristics of both smooth muscle cells and fibroblasts (Rothwell and Tingari, 1973; Aire and Ozegbe, 2007). As a result, peritubular myoid cells are immunopositive for desmin and actin, which are filaments characteristic of smooth muscle cells (Van Nassauw et al., 1993; Maretta and Marettova, 2004; Aire and Ozegbe, 2007). In addition, vimentin, an intermediate filament generally associated with fibroblasts, has also been immunolocalized in peritubular myoid cells (Aire and Ozegbe, 2007). Myoid cells in the peritubular boundary tissue and testicular capsule play an important role in the propulsion of spermatozoa from the seminiferous tubules into the excurrent duct system (Hargrove et al., 1977; Ellis et al., 1978, 1981; Banks et al., 2006).

The intermediate filaments desmin and vimentin, as well as the microfilament SMA, are integral parts of the cytoskeleton responsible for cytodifferentiation, maintenance of cell shape and cellular integrity (Amsterdam and Aharoni, 1994; Goldman et al., 1996; Galou et al., 1997). Antibodies against desmin, SMA and vimentin have been widely used to diagnose pathologies of the testicular capsule and peritubular lamina propria in humans (Jones et al., 1997; Deveci et al., 2002; Du et al., 2012). This is contrary to the situation in birds where pathologies of the testis have been studied mostly using histological and ultrastructural techniques (Leach et al., 2008; Golbar et al., 2009; Saied et al., 2011).

The Japanese quail has been successfully used as an avian model to study the effects of viruses and toxins on growth and reproductive activity (Rathnamohan, 1985; Bryan et al., 1989; Aire, 2005; Kamata et al., 2009). Information gained from studies on the Japanese quail has been used to assess the impact of viral and toxic agents on domestic and wild birds (Rathnamohan, 1985). Despite the extensive use of the Japanese quail in research, there is currently limited information available on the distribution of diagnostically important cytoskeletal proteins in the testis of this bird. The present study was undertaken to provide baseline information on the distribution of the intermediate filaments desmin and vimentin, as well as the microfilament SMA, in the testicular capsule and interstitial tissue of the Japanese quail from day 1 post-hatch to sexual maturity.

\section{Materials and Methods}

A total of 65 newly hatched male Japanese quail chicks were maintained in a temperature-controlled room, with a light regime of 14-h light/10-h dark. Feed and water were provided ad libitum. Five birds were administered with an intraperitoneal overdose of sodium pentobarbital anaesthetic (Sagatal, May and Baker, Port Elizabeth, South Africa) at 1, 3, 5, 7, 9, 11, 13, 15, 17, 24, 31, 38 and 60 days post-hatch. All the procedures used in this study were approved by the Animal Use and Care Committee of the University of Pretoria.

The thoraco-abdominal cavity was cut open, and the testes were removed. Testicular tissue was immersionfixed in $4 \%$ phosphate-buffered formaldehyde for $48 \mathrm{~h}$. After fixation, tissues were processed routinely for histology and embedded in paraffin wax. The immunostaining technique was performed on 5 - $\mu$ m-thick sections using a Universal LSAB-plus kit, Peroxidase (DakoCytomation, Glostrup, Denmark).

The sections were deparaffinized and rehydrated, and endogenous peroxidase activity was blocked, using a 3\% $(\mathrm{v} / \mathrm{v})$ hydrogen peroxide solution in water for $5 \mathrm{~min}$. The slides were then rinsed in a $0.01 \mathrm{M}$ phosphate-buffered saline solution (PBS, $\mathrm{pH} 7.4$ ) for $5 \mathrm{~min}$. Thereafter, the sections were microwaved at $750 \mathrm{~W}$ for three cycles of $7 \mathrm{~min}$ each in citrate buffer $\left(0.01 \mathrm{~mol} \times 1^{-1}, \mathrm{pH} \mathrm{6.0)}\right.$. After being allowed to cool for $20 \mathrm{~min}$, the sections were rinsed with PBS. The sections were then incubated for $30 \mathrm{~min}$ at room temperature with monoclonal antibodies against desmin, SMA and vimentin at dilutions of 1:50, 1:50 and 1:100, respectively. The primary antisera were purchased from DakoCytomation. The slides were then rinsed with $\mathrm{PBS}$ and then incubated for $15 \mathrm{~min}$ with a biotinylated secondary antibody (LSAB-plus kit). Thereafter, the slides were rinsed in PBS and subsequently incubated for $15 \mathrm{~min}$ with the streptavidin peroxidase component of the LSAB-plus staining kit. Slides were then rinsed in PBS, and bound antibody was visualized after the addition of a 3,3'-diaminobenzidine tetrachloride solution, diluted with a buffer supplied by the manufacturer (LSAB-plus kit). The sections were counter-stained with Mayer's haematoxylin.

In the negative controls, the monoclonal desmin, SMA and vimentin antibodies were replaced with mouse IgG1 (DakoCytomation). The negative control reagents were diluted to the same concentration as the primary antibodies. Bovine smooth muscle was used as a positive control for desmin and SMA, while bovine tonsillar tissue was used as a positive control for vimentin. Variations in the immunostaining of sections used in this study were minor. No background staining was detected in the negative control sections, while positive immunostaining for desmin, SMA and vimentin was observed in the control sections.

On the basis of visual examination, the relative intensities of desmin, SMA and vimentin immunostaining were designated as absent $(-)$, weak $(+)$, moderate $(++)$ and strong $(+++)$ as described previously (Madekurozwa and Kimaro, 2006). 


\section{Results}

\section{Testicular capsule}

The testes were enclosed in a testicular capsule composed of a tunica serosa, tunica albuginea and tunica vasculosa. The immunostaining intensities of desmin, SMA and vimentin in various cells of the testicular capsule are summarized in Table 1.

\section{Tunica serosa}

The tunica serosa, in 1- to 13-day-old quails, comprised a single layer of mesothelial cells, with ovoid nuclei and prominent nucleoli. In the 15- to 60-day-old quails, the mesothelial cells contained elongated nuclei.

The mesothelial cells in all age groups studied were desmin and SMA immunonegative. The cytoplasm of the mesothelial cells displayed weak vimentin immunostaining in the 1- to 3-day-old quails. Strong vimentin immunostaining was demonstrated in the mesothelial cells from day 5 post-hatch (Fig. 1a).

\section{Tunica albuginea}

Four to five cell layers, interspersed with small amounts of loose connective tissue, formed the tunica albuginea in 1- to 5-day-old quails. Cells in the outer zone of the tunica albuginea contained ovoid to oblong nuclei and cytoplasm which was desmin and SMA immunonegative. Cells in the inner zone contained elongated nuclei and desmin-immunopositive cytoplasm (Fig. 1b). The cytoplasm of these cells was SMA immunonegative.

Table 1. Desmin, smooth muscle actin (SMA) and vimentin immunoexpression in the developing testicular capsule

\begin{tabular}{lllll}
\hline \multirow{2}{*}{ Age (days) } & Antibody & Tunica serosa & Tunica albuginea & $\begin{array}{l}\text { Tunica } \\
\text { vasculosa }\end{array}$ \\
\hline $1-3$ & Desmin & - & $-/++$ & $++/+++^{a}$ \\
& SMA & - & - & $++/+++^{a}$ \\
& Vimentin & + & ++ & $+++^{\mathrm{b}}$ \\
5 & Desmin & - & $-/++$ & $++/+++^{\mathrm{a}}$ \\
& SMA & - & - & $++/+++^{\mathrm{a}}$ \\
& Vimentin & +++ & ++ & $+++^{\mathrm{b}}$ \\
$7-24$ & Desmin & - & $-/++/+++$ & $++/+++^{\mathrm{a}}$ \\
& SMA & - & $-/++/+++$ & $++/+++^{\mathrm{a}}$ \\
& Vimentin & +++ & ++ & $+++^{\mathrm{b}}$ \\
$31-60$ & Desmin & - & +++ & $++/+++^{\mathrm{a}}$ \\
& SMA & - & +++ & $++/+++^{\mathrm{a}}$ \\
& Vimentin & +++ & ++ & $+++^{\mathrm{b}}$ \\
\hline
\end{tabular}

Intensities of immunostaining: -, absent; +, weak; ++, moderate; +++ , strong.

aTunica media.

${ }^{\mathrm{b}}$ Endothelium.
Approximately 11-13 cell layers formed the tunica albuginea in the 7 - to 24-day-old quails. The outer zone of the tunica albuginea was desmin and SMA immunonegative, while moderate-to-strong immunostaining for desmin (Fig. 1c) and SMA was demonstrated in the inner zone. The tunica albuginea in 31- to 60-day-old quails was formed by 5-8 layers of cells with elongated nuclei. Interposed between the cells were collagen fibre bundles. Although fewer cell layers were observed in the tunica albuginea of 31- to 60-day-old birds, the layer was thicker than in 7- to 24-day-old quails due to the presence of intervening collagen fibre bundles. Strong desmin and SMA (Fig. 1d) immunostaining was demonstrated in all cell layers forming the tunica albuginea in these age groups. Although the intensity of immunostaining did not vary, the quantity of immunoreaction deposits in the cell layers varied.

Vimentin immunostaining in the tunica albuginea of all age groups was observed in a few fibroblasts that were scattered throughout the layer.

\section{Tunica vasculosa}

The tunica vasculosa in all quails studied was located adjacent to the testicular parenchyma (Fig. 1b,d). In addition, large blood vessels were present in the superficial regions of the tunica albuginea from day 7 post-hatch. In all age groups, the tunica media of larger blood vessels, within the tunica vasculosa, displayed moderate-to-strong desmin (Fig. 1b) and SMA (Fig. 1d) immunostaining. Strong vimentin immunostaining was present in the endothelial cells of the blood vessels (not shown).

\section{Interstitial tissue}

The immunostaining intensities of desmin, SMA and vimentin in various cells of the interstitial tissue are summarized in Table 2.

\section{Mesenchymal cells}

The intertubular areas in 1- to 13-day-old quails were dominated by mesenchymal cells, which were characterized by the presence of oblong-shaped nuclei with prominent nucleoli. Very few mesenchymal cells were observed in the 15- and 17-day-old quails. Intertubular areas in 24- to 60-day-old quails were devoid of mesenchymal cells.

The mesenchymal cytoplasm displayed moderateto-strong desmin immunostaining (Fig. 2a), while SMA immunostaining was weak or absent (Fig. 2b). The mesenchymal cells were vimentin immunonegative (Fig. 1a). 


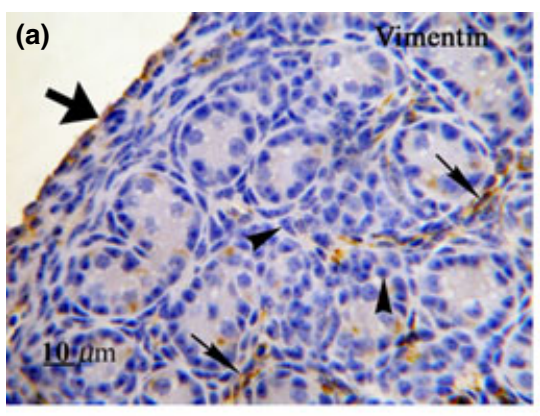

(c)

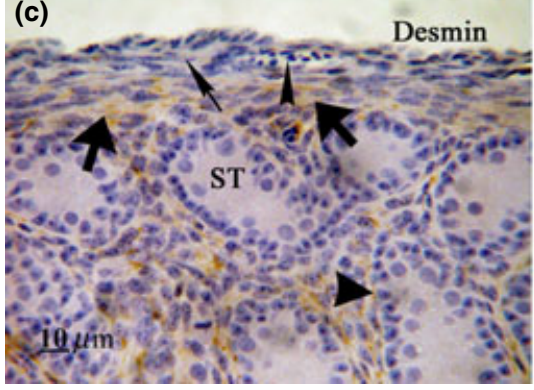

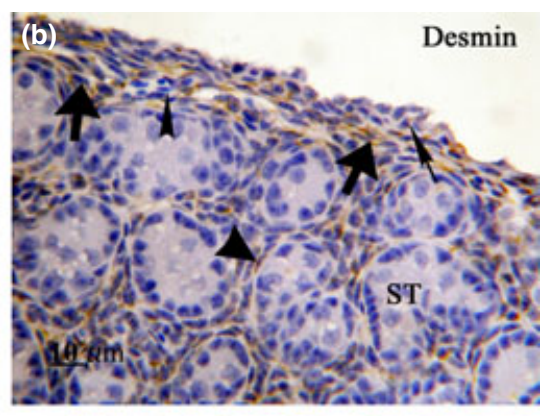

(d)

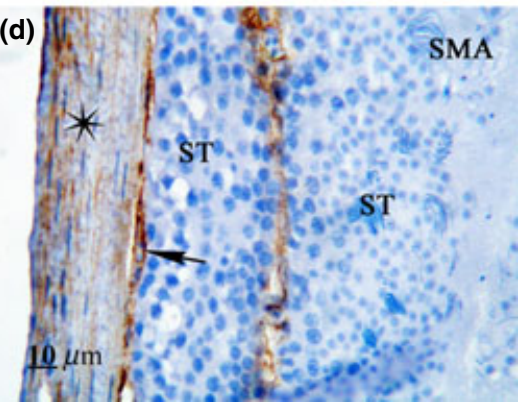

Fig. 1. Testicular capsule (a) 5 days posthatch. Immunostaining in mesothelial (thick arrow) and endothelial (thin arrows) cells. Arrowheads: immunonegative mesenchymal cells. (b) 1 day and (c) 17 days post-hatch. Immunopositive inner zone (thick arrows) and immunonegative outer zone (thin arrows) of the tunica albuginea. Thick arrowheads: immunopositive peritubular myoid cells. Thin arrowheads: tunica vasculosa. ST, seminiferous tubules. (d) 60 days post-hatch. Immunopositive tunica albuginea (asterisk). Arrow: tunica vasculosa containing blood vessels with immunopositive tunica media. ST, seminiferous tubules.
Table 2. Desmin, smooth muscle actin (SMA) and vimentin immunoexpression in cells of the developing interstitial tissue

\begin{tabular}{|c|c|c|c|c|c|}
\hline Age (days) & Antibody & Mesenchymal & Myoid & Leydig & $\begin{array}{l}\text { Fibroblast/ } \\
\text { Fibrocyte }\end{array}$ \\
\hline \multirow[t]{3}{*}{1} & Desmin & $++/+++$ & +++ & +++ & +++ \\
\hline & SMA & $-/+$ & + & - & - \\
\hline & Vimentin & - & - & - & - \\
\hline \multirow[t]{3}{*}{$3-5$} & Desmin & $++/+++$ & +++ & +++ & +++ \\
\hline & SMA & $-/+$ & + & - & - \\
\hline & Vimentin & - & - & - & ++ \\
\hline \multirow[t]{3}{*}{7} & Desmin & $++/+++$ & +++ & +++ & +++ \\
\hline & SMA & $-/+$ & ++ & - & - \\
\hline & Vimentin & - & - & - & ++ \\
\hline \multirow[t]{3}{*}{9} & Desmin & $++/+++$ & +++ & +++ & +++ \\
\hline & SMA & $-/+$ & ++ & - & - \\
\hline & Vimentin & - & - & ++ & ++ \\
\hline \multirow[t]{3}{*}{11} & Desmin & $++/+++$ & +++ & +++ & +++ \\
\hline & SMA & $-1+$ & ++ & - & - \\
\hline & Vimentin & - & - & +++ & ++ \\
\hline \multirow[t]{3}{*}{13} & Desmin & $++/+++$ & +++ & $+/++$ & $++/+++$ \\
\hline & SMA & $-/+$ & ++ & - & - \\
\hline & Vimentin & - & $+/++$ & +++ & ++ \\
\hline \multirow[t]{3}{*}{$15-17$} & Desmin & $++/+++$ & +++ & $+/++$ & $-1+$ \\
\hline & SMA & $-/+$ & ++ & - & - \\
\hline & Vimentin & - & $+/++$ & +++ & ++ \\
\hline \multirow[t]{3}{*}{ 24-31 } & Desmin & 0 & +++ & $+/++$ & - \\
\hline & SMA & 0 & +++ & - & - \\
\hline & Vimentin & 0 & $+/++$ & +++ & ++ \\
\hline \multirow[t]{3}{*}{$38-60$} & Desmin & 0 & +++ & $+/++$ & - \\
\hline & SMA & 0 & +++ & - & - \\
\hline & Vimentin & 0 & +++ & +++ & ++ \\
\hline
\end{tabular}

Intensities of immunostaining: -, absent; +, weak; ++, moderate; +++ , strong. 0: Cell not observed.
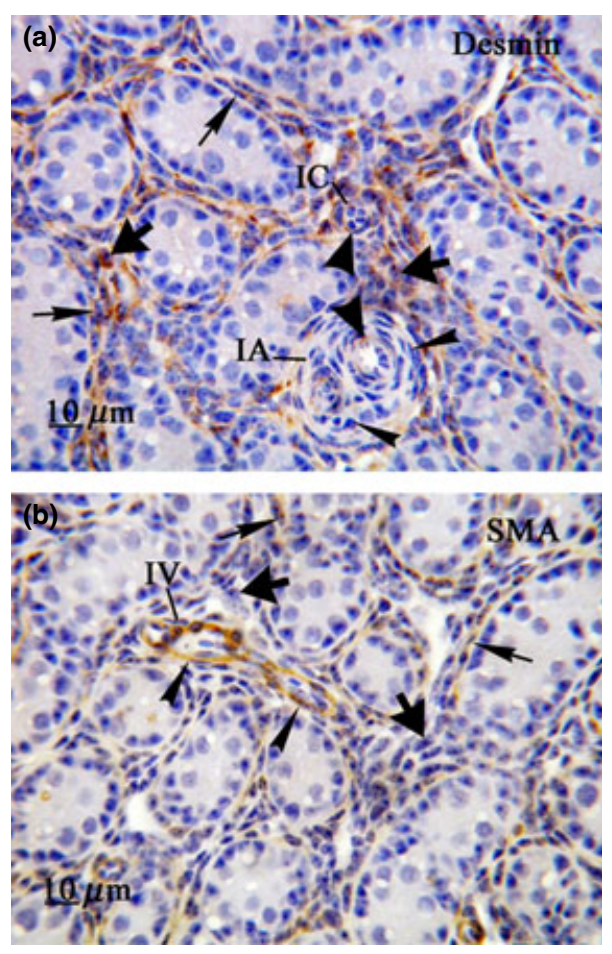

Fig. 2. Testicular interstitial tissue. 11 days post-hatch. (a) Immunopositive mesenchymal cells (thick arrows), peritubular myoid cells (thin arrows) and vascular smooth muscle cells (thick arrowheads). Thin arrowheads: immunonegative vascular smooth muscle cells. IA, intertubular arteriole; IC, intertubular capillary. (b) Thick arrows: immunonegative mesenchymal cells. Immunostaining in peritubular myoid (thin arrows) and vascular smooth muscle (arrowheads) cells. IV, intertubular venule. 


\section{Peritubular myoid cells}

Encircling the seminiferous tubules in 1- to 11-day-old quails was a single layer of peritubular myoid cells with ovoid nuclei. Seminiferous tubules surrounded by two layers of peritubular myoid cells were occasionally observed in 13-, 15- and 17-day-old quails. Seminiferous tubules in the 24- and 31-day-old quails contained spermatids with elongated nuclei, while spermatozoa were present in the 38- and 60-day-old birds. A single layer of peritubular myoid cells encircled the seminiferous tubules in 24- to 60-day-old quails.

Peritubular myoid cells in all quails studied exhibited strong desmin immunostaining (Fig. 2a). Weak SMA immunostaining was demonstrated in peritubular myoid cells of 1- to 5-day-old quails, while moderate SMA immunostaining was present in 7- to 17-day-old quails (Fig. 2b). Strong SMA (Fig. 3a) immunostaining was demonstrated in the peritubular myoid cells of 24- to 60-day-old quails. Peritubular myoid cells in 1- to 11day-old quails were vimentin immunonegative. Occasional peritubular myoid cells exhibiting weak-to-moderate vimentin immunostaining were observed in 13- to 31day-old quails. Strong vimentin immunostaining was demonstrated in the majority of peritubular myoid cells in the 38- and 60-day-old quails (Fig. 3b).
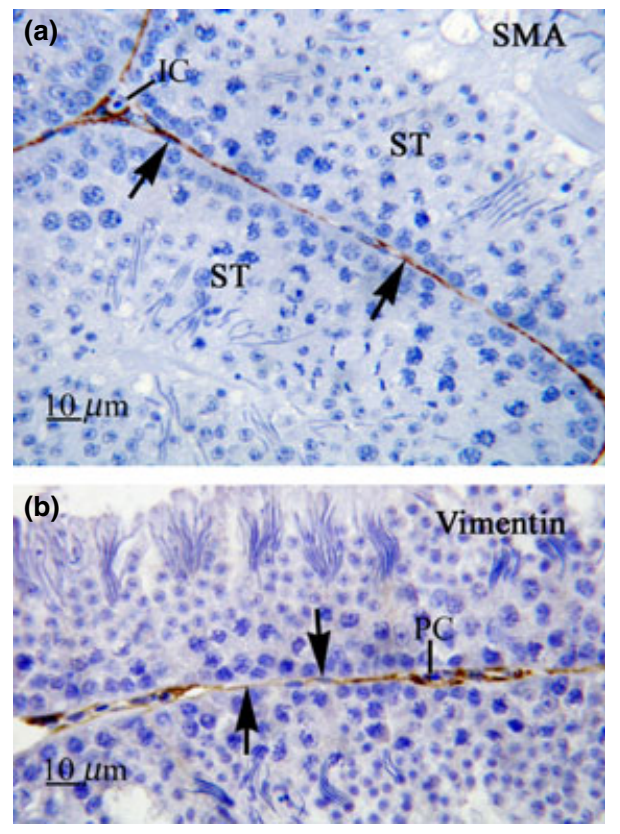

Fig. 3. Testicular interstitial tissue in adult quails. (a) 31 days posthatch. Seminiferous tubules (ST) encircled by a single layer of immunopositive peritubular myoid cells (arrows). IC, intertubular capillary. (b) 60 days post-hatch. Immunopositive peritubular myoid cells (arrows). PC, peritubular capillary.
Leydig cells

In the 1- to 13-day-old quails, groups of 3-4 Leydig cells were observed in the intertubular areas, usually close to blood vessels. The Leydig cells were characterized by the presence of spherical nuclei with 1 or 2 prominent nucleoli (Fig. 4b). The interstitial tissue of 15- and 17-day-old quails was dominated by Leydig cells (Fig. 4d). In 24- to 60 -day-old quails, Leydig cells were generally confined to the interstitium between three adjacent seminiferous tubules.

Strong desmin immunostaining was demonstrated in Leydig cells of 1- to 11-day-old quails. Leydig cells in 13- to 60-day-old quails displayed weak-to-moderate desmin immunostaining (Fig. 4a). Leydig cells in all age groups were SMA immunonegative. Leydig cells in 1to 7-day-old quails were vimentin immunonegative (Fig. 4b). Vimentin immunostaining (Fig. 4c,d) was exhibited by Leydig cells from day 9 post-hatch.

\section{Fibroblasts}

Fibroblasts in the intertubular regions of 1- to 17-day-old quails contained oval to elongated nuclei with prominent nucleoli. Fibrocytes with dark, elongated nuclei were observed in the 24- to 60-day-old quails.

Desmin-immunopositive fibroblasts were only observed in 1- to 17-day-old quails. Fibroblasts and fibrocytes in all quails studied were SMA immunonegative. Vimentin immunostaining was observed in fibroblasts from day 3 post-hatch (Fig. 5a).

\section{Interstitial blood vessels}

Blood vessels were observed in the interstitial tissues of all quails studied. Intertubular arterioles (Figs $2 \mathrm{a}$ and $4 \mathrm{a}, \mathrm{b}, \mathrm{d}$ ), capillaries (Figs 2a and 5b) and venules (Figs 2b, 4a and 5a) were situated in the wide interstitial spaces formed between adjoining seminiferous tubules. Peritubular capillaries (Figs $3 \mathrm{~b}$ and $5 \mathrm{~b}$ ) coursed through the narrow interstitial spaces between adjacent seminiferous tubules. Lymphatic vessels were not discernible. Interstitial blood vessels were frequently associated with Leydig cells (Fig. 4a,d).

The tunica intima of the interstitial blood vessels was composed of a single layer of endothelial cells. The tunica media of intertubular arterioles was formed by 3-6 smooth muscle cell layers. Intertubular venules contained large lumina lined by endothelial cells and a single layer of smooth muscle cells. Intertubular and peritubular capillaries were formed by endothelial cells with an enclosing layer of pericytes.

Endothelial cells in all age groups were desmin and SMA immunonegative. The endothelial cells in all quails 

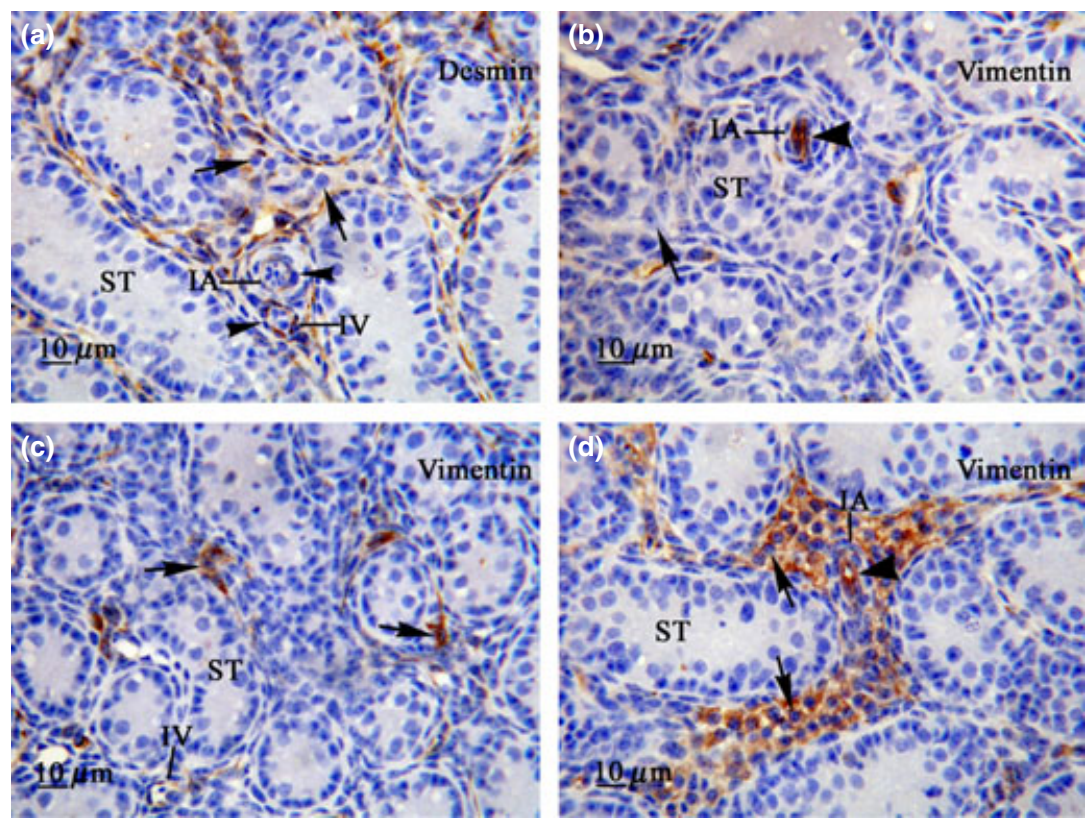

Fig. 4. Leydig cells in the interstitium. (a) 13, (b) 7, (c) 11 and (d) 15 days post-hatch. Arrows: Leydig cells. Thick arrowheads: immunopositive endothelial cells. Thin arrowheads: immunopositive vascular smooth muscle cells. IA, intertubular arteriole; IV, intertubular venule; ST, seminiferous tubule.
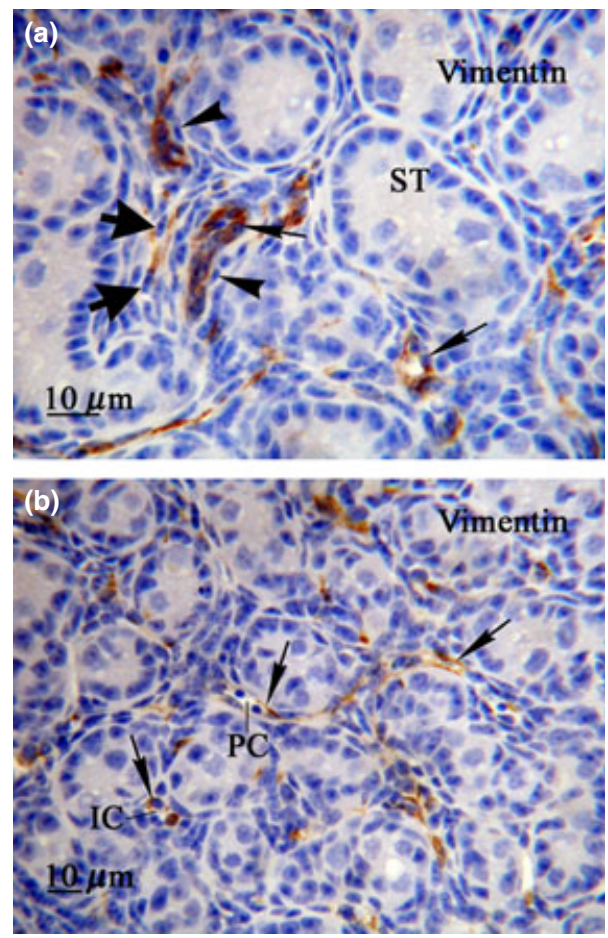

Fig. 5. Testicular interstitial tissue. 3 days post-hatch. (a) Thick arrows: immunopositive fibroblasts. Thin arrows: immunopositive endothelial cells lining intertubular venules. Arrowheads: immunonegative tunica media. ST, seminiferous tubule. (b) Arrows: immunopositive endothelial cells. IC, intertubular capillary;PC, peritubular capillary.

studied displayed strong vimentin immunostaining (Figs $4 \mathrm{~b}$ and $5 \mathrm{a}$ ). The inner tunica media regions of intertubular arterioles in 1- to 17-day-old quails were moderately or strongly immunopositive for desmin (Figs 2a and 4a) and SMA, but immunonegative for vimentin (Fig. 4b). Desmin (Fig. 2a) and SMA immunostaining in the outer smooth muscle cells of intertubular arterioles in 1- to 13-day-old quails was weak or absent. Weak-to-moderate desmin and SMA immunostaining was exhibited by peripheral smooth muscle cells of intertubular arterioles in 15- and 17-day-old quails. The tunica media of intertubular arterioles in 24- to 60-day-old quails displayed strong, uniform desmin and SMA immunostaining.

Pericytes associated with intertubular and peritubular capillaries were immunoreactive for desmin (Fig. 2a) and SMA in all quails studied. Intertubular and peritubular (Figs $3 \mathrm{~b}$ and 5b) capillary endothelial cells exhibited strong vimentin immunostaining.

The tunica media of intertubular venules was immunopositive for both desmin (Fig. 4a) and SMA (Fig. 2b), while the endothelial lining was vimentin immunopositive (Fig. 5a).

\section{Discussion}

\section{Testicular capsule}

In agreement with a report on the post-hatch domestic fowl (Gonzalez-Moran and Soria-Castro, 2010), myoid cells were a major component of the early post-hatch tunica albuginea in the Japanese quail. These findings are contrary to observations made of the tunica albuginea in the early post-natal rabbit, in which the layer was composed predominantly of fibroblasts, with few myoid cells observed (Leeson and Forman, 1981). 
In the current study, myoid cells in the tunica albuginea were characterized by the presence of desmin and SMA. These cytoskeletal proteins have also been immunolocalized in the tunica albuginea of other avian species including the domestic fowl (Maretta and Marettova, 2004; Abd-Elmaksoud, 2009), ratites (Ozegbe et al., 2008) and masked weaver (Ozegbe et al., 2012).

Reports on the immunolocalization of desmin and SMA in adult birds have shown the existence of a species-specific zonation of these cytoskeletal proteins in the tunica albuginea. Thus, in the emu (Ozegbe et al., 2008) and domestic fowl (Abd-Elmaksoud, 2009), SMA immunoreactivity was restricted to the inner zone of the tunica albuginea. Conversely, in the ostrich, SMA immunostaining was confined to the outer zone of the tunica albuginea (Ozegbe et al., 2008). Desmin has been localized in the inner tunica albuginea zone in the emu and in the outer zone in the ostrich (Ozegbe et al., 2008). Interestingly, in the present report, immunostaining for desmin and SMA was restricted to the inner zone of the tunica albuginea in the 7- to 24-day-old quails. However, immunostaining for desmin and SMA was distributed uniformly in the tunica albuginea of the adult quails. These findings indicate that the zonal arrangement of desmin and SMA immunostaining in the tunica albuginea of the Japanese quail is age dependent.

In the current study, vimentin was demonstrated in fibroblasts within the tunica albuginea. The presence of vimentin immunoreactivity in the avian tunica albuginea is species dependent. Researchers have shown that the tunica albuginea of the Japanese quail, turkey and emu is vimentin immunopositive, while that of the domestic fowl, duck, ostrich and masked weaver is immunonegative (Aire and Ozegbe, 2007; Ozegbe et al., 2008, 2012).

In the current study, the tunica vasculosa was observed adjacent to the testicular parenchyma from day 1 post-hatch. This is in agreement with findings in the post-natal buffalo (Goyal and Dhingra, 1973) and rabbit (Leeson and Forman, 1981). Ultrastructural and immunohistochemical techniques have been used to study the tunica vasculosa in several avian species (Aire and Ozegbe, 2007; Ozegbe et al., 2008). In general, the tunica vasculosa in birds is poorly developed, with few blood vessels extending into the parenchyma (Aire and Ozegbe, 2007).

The immunolocalization of vimentin in endothelial cells of the tunica vasculosa in the post-hatch quail was in agreement with reports in the emu and ostrich (Ozegbe et al., 2008). Furthermore, the immunoexpression of desmin and SMA in smooth muscle cells of the tunica vasculosa was similar to that reported in the adult Japanese quail, turkey, domestic fowl and duck (Aire and Ozegbe, 2007).

\section{Interstitial tissue}

Mesenchymal cells were a prominent feature of the interstitial tissue in 1- to 13-day-old quails. The mesenchymal cells were immunopositive for desmin, but immunonegative for vimentin. SMA immunostaining in these cells was weak or absent. In contrast, mesenchymal cells in the testis of post-natal sheep were immunopositive for desmin and vimentin, but immunonegative for SMA (Steger and Wrobel, 1994). Despite the low levels or the absence of SMA immunoexpression, mesenchymal cells are regarded as pluripotent cells, which differentiate into peritubular myoid cells, Leydig cells and fibroblasts (Wrobel et al., 1988).

The number of peritubular myoid cell layers encircling seminiferous tubules is species dependent. In the posthatch Japanese quail, a single layer of peritubular myoid cells surrounded the seminiferous tubules, except in the 13-, 15- and 17-day-old birds, where two cell layers were occasionally observed. This is contrary to observations made in the post-hatch domestic fowl in which seminiferous tubules were surrounded by several layers of peritubular myoid cells (Gonzalez-Moran and Soria-Castro, 2010). In mammals, the number of peritubular myoid cell layers encircling seminiferous tubules varies with the species, as well as the stage of testicular maturation. At birth, several layers of peritubular myoid cells surround the seminiferous tubules in the opossum (Xie et al., 1996) and rat (Ariyaratne and Mendis-Handagama, 2000). In these species, the number of peritubular myoid cell layers decreases with testicular maturation.

Peritubular myoid cells in the post-hatch Japanese quail exhibited strong desmin immunostaining during all stages of testicular development. The expression of desmin in peritubular myoid cells is species and age dependent. In agreement with observations in the present report, desmin was expressed by peritubular myoid cells in the rat and humans during all testicular developmental stages (Virtanen et al., 1986; Palombi et al., 1992; Scipioni et al., 2005). In contrast, desmin immunostaining in the peritubular myoid cells of sheep was weak in the neonate and absent in the adult (Steger and Wrobel, 1994). In a manner similar to SMA, desmin is regarded as a reliable marker for peritubular myoid differentiation (Virtanen et al., 1986).

In the present study, the development of strong SMA immunostaining in peritubular myoid cells coincided with the formation of elongated spermatids in the seminiferous tubules. An increase in the intensity of SMA immunostaining in relation to testicular maturation has been reported in the rat (Palombi et al., 1992), sheep (Steger and Wrobel, 1994), porpoise (Holt et al., 2004) and bovine (Devkota et al., 2006). Due to the increase in 
the intensity of immunostaining during development, SMA is regarded as a marker for peritubular myoid cell differentiation (Tung and Fritz, 1990).

Species-specific and age-dependent variations also exist in the immunolocalization of vimentin in peritubular myoid cells. In the present report, strong immunostaining for vimentin in peritubular myoid cells occurred only in the adult testis. This is contrary to observations in the sheep (Steger and Wrobel, 1994) and bovine (Devkota et al., 2006). Peritubular myoid cells expressed vimentin during the early post-natal period in sheep (Steger and Wrobel, 1994), while in the bovine (Devkota et al., 2006) vimentin was expressed in all stages of post-natal development.

Leydig cells were a dominant feature of the interstitial tissue in 15- and 17-day-old quails. Observations on the post-natal development of Leydig cells in mammals have shown that the arrangement and number of these cells in the interstitial tissue change with testicular maturation (Goyal and Dhingra, 1973; Deanesly, 1977; Leeson and Forman, 1981; Xie et al., 1996; Ariyaratne and MendisHandagama, 2000). Similarly, in the present study, the groupings and location of Leydig cells varied as the testis matured. The morphology of Leydig cells in the current report was as previously described in the Japanese quail (Nicholls and Graham, 1972) and ostrich (Madekurozwa et al., 2002).

In the present study, Leydig cells, in all except the 1- to 7-day-old quails, were immunoreactive for vimentin. Vimentin has previously been demonstrated in Leydig cells in the bear (Komatsu et al., 1998), rodent (Ortega et al., 2004) and horse (Lydka et al., 2011). The immunolocalization of vimentin in Leydig cells is indicative of the mesenchymal origin of these cells (Wrobel et al., 1988; Chemes et al., 1992).

An interesting finding of the present study was the occurrence of desmin in the fibroblasts of 1- to 17day-old quails. Although mature fibroblasts are generally desmin immunonegative, differentiating fibroblasts are immunopositive for desmin (Han et al., 2011). In contrast to desmin, vimentin is a ubiquitous marker for fibroblasts (Lazarides, 1980; Wang and Stamenovic, 2002). However, in the current study, vimentin-immunoreactive fibroblasts were present only from day 3 post-hatch. This finding is contrary to observations made in the pig, in which testicular fibroblasts were vimentin immunopositive from birth (Liu et al., 2009).

In the current investigation, an extensive network of interstitial blood vessels was present from day 1 posthatch. In addition, immunostaining for desmin, SMA and vimentin was already present at this stage. These findings correlate well with observations of interstitial blood vessels in the developing testes of the sheep (Steger and
Wrobel, 1994), harbour porpoise (Holt et al., 2004) and bovine (Wrobel et al., 1995; Devkota et al., 2006). In the current study, Leydig cells were observed in close proximity to the interstitial blood vessels. This finding has also been noted in the bovine (Wrobel et al., 1988) and rat (Ariyaratne and Mendis-Handagama, 2000; Tran et al., 2006). It is known that the interaction between Leydig cells and interstitial blood vessels is essential for the maintenance of normal Leydig cell steroidogenesis and testicular blood flow (Haider, 2004; Welsh et al., 2010).

In conclusion, the results of this study have established that the intensity and distribution of desmin, SMA and vimentin immunostaining, in the testicular capsule and interstitial tissue of the post-hatch Japanese quail, changes with testicular maturation.

\section{Acknowledgements}

The author thanks staff in the Department of Pathology, University of Pretoria, for their assistance. The National Research Foundation funded this study.

\section{References}

Abd-Elmaksoud, A., 2009: Comparative expression of laminin and smooth muscle actin in the testis and epididymis of poultry and rabbit. J. Mol. Histol. 40, 407-416.

Aire, T. A., 1997: The structure of the interstitial tissue of the active and resting avian testis. Onderstepoort J. Vet. Res. 64, 291-299.

Aire, T. A., 2005: Short term effects of carbendazim on the gross and microscopic features of the testes of Japanese quails (Coturnix coturnix japonica). Anat. Embryol. 210, 43-49.

Aire, T. A., and P. C. Ozegbe, 2007: The testicular capsule and peritubular tissue of birds: morphometry, histology, ultrastructure and immunohistochemistry. J. Anat. 210, 731-740.

Amsterdam, A., and D. Aharoni, 1994: Plasticity of cell organization during differentiation of normal and oncogene transformed granulosa cells. Microsc. Res. Tech. 27, 108-124.

Ariyaratne, H. B. S., and S. M. L. C. Mendis-Handagama, 2000: Changes in the testis interstitium of Sprague Dawley rats from birth to sexual maturity. Biol. Reprod. 62, 680690.

Banks, F. C. L., G. E. Knight, R. C. Calvert, M. Turmaine, C. S. Thompson, D. P. Mikhailidis, R. J. Morgan, and G. Burnstock, 2006: Smooth muscle and purinergic contraction of the human, rabbit, rat, and mouse testicular capsule. Biol. Reprod. 74, 473-480.

Bryan, T. E., R. P. Gildersleeve, and R. P. Ward, 1989: Exposure of Japanese quail embryos to o.p'-DDT has long term effects on reproductive behaviours, hematology and feather morphology. Teratology 39, 525-535.

Chacon-Arellano, J. T., and D. M. Woolley, 1980: Smooth muscle cells in the testicular capsule of the horse, pig and sheep. J. Anat. 131, 263-273. 
Chemes, H., S. Cigorraga, C. Bergada, H. Schteingart, R. Rey, and E. Pellizzari, 1992: Isolation of human Leydig cell mesenchymal precursors from patients with the androgen insensitivity syndrome: testosterone production and response to human chorionic gonadotropin stimulation in culture. Biol. Reprod. 46, 793-801.

Deanesly, R., 1977: Testis differentiation in the fetal and postnatal ferret. J. Anat. 123, 589-599.

Deveci, M. S., G. Deveci, O. Onguru, M. Kilciler, and B. Celasun, 2002: Testicular (gonadal stromal) fibroma: case report and review of the literature. Pathol. Int. 52, 326-330. Devkota, B., M. Sasaki, K.-I. Takahashi, S. Matsuzaki, M. Matsui, S. Haneda, M. Takahashi, T. Osawa, and Y.-I. Miyake, 2006: Post-natal developmental changes in immunohistochemical localization of alpha-smooth muscle actin (SMA) and vimentin in bovine testes. J. Reprod. Dev. 52, 43-49. Du, S., J. Powell, A. Hii, and N. Weidner, 2012: Myoid gonadal stromal tumor: a distinct testicular tumor with peritubular myoid cell differentiation. Hum. Pathol. 43, 144-149. Ellis, L. C., L. F. Buhrley, and J. L. Hargrove, 1978: Species differences in contractility of seminiferous tubules and tunica albuginea as related to sperm transport through the testis. Arch. Androl. 1, 139-146.

Ellis, L. C., M. D. Groesbeck, C. H. Farr, and R. J. Tesi, 1981: Contractility of seminiferous tubules as related to sperm transport in the male. Arch. Androl. 6, 283-294.

Galou, M., J. Gao, J. Humbert, M. Mericskay, Z. Li, D. Paulin, and P. Vicart, 1997: The importance of intermediate filaments in the adaptation of tissues to mechanical stress: evidence from gene knockout studies. Biol. Cell 89, 85-97.

Golbar, H. M., T. Izawa, M. Kuwamura, M. Yonezawa, S. Ito, and J. Yamate, 2009: Malignant seminoma with multiple visceral metastases in a guinea fowl (Numida meleagris) kept in a zoo. Avian Dis. 53, 143-145.

Goldman, R. D., S. Khuon, Y. H. Chou, P. Opal, and P. M. Steinert, 1996: The function of intermediate filaments in cell shape and cytoskeletal integrity. J. Cell Biol. 134, 971-983.

Gonzalez-Moran, M. G., and E. Soria-Castro, 2010: Changes in the tubular compartment of the testis of Gallus domesticus during development. British Poult. Sci. 51, 296-307.

Goyal, H. O., and L. D. Dhingra, 1973: A study on the postnatal histology of the testis in buffalo (Bubalis bubalis). I. From birth to one year. Acta Anat. 84, 237-250.

Haider, S. G., 2004: Cell biology of Leydig cells in the testis. Int. Rev. Cytol. 233, 181-241.

Han, Y., J. Chai, T. Sun, D. Li, and R. Tao, 2011: Differentiation of human umbilical cord mesenchymal stem cells into dermal fibroblasts in vitro. Biochem. Biophy. Res. Comm. 413, 561-565.

Hargrove, J. L., J. H. MacIndoe, and L. C. Ellis, 1977: Testicular contractile cells and sperm transport. Fertil. Steril. 28, 1146-1157.

Holt, W. V., J. Waller, A. Moore, P. D. Jepson, R. Deaville, and P. M. Bennett, 2004: Smooth muscle actin and vimentin as markers of testis development in the harbour porpoise (Phocoena phocoena). J. Anat. 205, 201-211.
Jones, M. A., R. H. Young, and R. E. Scully, 1997: Benign fibromatous tumors of the testis and paratesticular region: a report of 9 cases with a proposed classification of fibromatous tumors and tumor-like lesions. Am. J. Surg. Pathol. 21, 296-305.

Kamata, R., F. Shiraishi, S. Takahashi, A. Shimizu, and H. Shiraishi, 2009: Reproductive and developmental effects of transovarian exposure to o.p'-DDT in Japanese quails. Environ. Tox. Chem. 28, 782-790.

Komatsu, T., Y. Yamamoto, Y. Atoji, T. Tsubota, and Y. Suzuki, 1998: Immunohistochemical demonstration of cytoskeletal proteins in the testis of the Japanese black bear, Ursus thibetanus japonicas. Anat. Histol. Embryol. 27, 209213.

Lazarides, E., 1980: Intermediate filaments as mechanical integrators of cellular space. Nature 283, 249-256.

Leach, S., J. J. Heatley, R. R. Pool, and K. Spaulding, 2008: Bilateral testicular germ cell-sex cord-stromal tumor in a pekin duck (Anas platyrhynchos domesticus). J. Avian Med. Surg. 22, 315-319.

Leeson, C. R., and D. E. Forman, 1981: Post-natal development and differentiation of contractile cells within the rabbit testis. J. Anat. 132, 491-511.

Liu, H.-B., P.-R. Lu, X.-G. Yang, X.-E. Qin, D.-Y. Pi, Y.-Q. Lu, K.-H. Lu, S.-S. Lu, and D.-S. Li, 2009: Fibroblasts from the new-born male testicle of Guangxi Bama mini pig (Sus scrofa) can support nuclear transferred embryo development in vitro. Zygote 17, 147-156.

Lydka, M., M. Kotula-Balak, I. Kopera-Sobota, M. Tischner, and B. Bilinska, 2011: Vimentin expression in testes of Arabian stallions. Equine Vet. J. 43, 184-189.

Madekurozwa, M.-C., and W. H. Kimaro, 2006: A morphological and immunohistochemical study of healthy and atretic follicles in the ovary of the sexually immature ostrich (Struthio camelus). Anat. Histol. Embryol. 35, 253-258.

Madekurozwa, M.-C., T. S. Chabvepi, S. Matema, and K. J. Teerds, 2002: Relationship between seasonal changes in spermatogenesis in the juvenile ostrich (Struthio camelus) and the presence of the LH receptor and $3 \mu$-hydroxysteroid dehydrogenase. Reproduction 123, 735-742.

Maretta, M., and E. Marettova, 2004: Immunohistochemical demonstration of smooth muscle cells in the testis and its excurrent ducts in the domestic fowl. British Poult. Sci. 45, 585-589.

Nicholls, T. J., and G. P. Graham, 1972: Observations on the ultrastructure and differentiation of Leydig cells in the testis of the Japanese quail (Coturnix coturnix japonica). Biol. Reprod. 6, 179-192.

Ortega, H. H., J. A. Lorente, and N. R. Salvetti, 2004: Immunohistochemical study of intermediate filaments and neuroendocrine marker expression in Leydig cells of laboratory rodents. Anat. Histol. Embryol. 33, 309-315.

Ozegbe, P. C., T. A. Aire, M.-C. Madekurozwa, and J. T. Soley, 2008: Morphological and immunohistochemical study of testicular capsule and peritubular tissue of emu (Dromaius 
novaehollandiae) and ostrich (Struthio camelus). Cell Tiss.

Res. 332, 151-158.

Ozegbe, P. C., T. A. Aire, and M. S. Deokar, 2012: The cytoskeletal proteins in the contractile tissues of the testis and its excurrent ducts of the passerine bird, masked weaver (Ploceus velatus). Tissue Cell 44, 22-31.

Palombi, F., D. Farini, M. Salanova, S. De Grossi, and M. Stefanini, 1992: Development and cytodifferentiation of peritubular myoid cells in the rat testis. Anat. Rec. 233, 32-40.

Rathnamohan, N., 1985: The management of Japanese quail and their use in virological research: a review. Vet. Res.

Comm. 9, 1-14.

Rothwell, B., 1975: Designation of the cellular component of the peritubular boundary tissue of the seminiferous tubule in the testis of the fowl (Gallus domesticus). British Poult.

Sci. 16, 527-529.

Rothwell, B., and M. D. Tingari, 1973: The ultrastructure of the boundary tissue of the seminiferous tubule in the testis of the domestic fowl (Gallus domesticus). J. Anat. 114, 321-328.

Saied, A., H. Beaufrere, T. N. Tully, and N. Wakamatsu, 2011: Bilateral seminoma with hepatic metastasis in a cockatiel (Nymphicus hollandicus). J. Avian Med. Surg. 25, 126-131.

Santamaria, L., A. Reoyo, J. Regadera, and R. Paniagua, 1990: Histochemistry and ultrastructure of nerve fibres and contractile cells in the tunica albuginea of the rat testis. Acta Anat. 139, 126-133.

Scipioni, A., S. Stefanini, R. Santone, and M. Giorgi, 2005: Immunohistochemical localization of PDE5 in Leydig and smooth muscle cells of prepubertal and adult rat testis. Histochem. Cell Biol. 124, 401-407.

Steger, K., and K.-H. Wrobel, 1994: Immunohistochemical demonstration of cytoskeletal proteins in the ovine testis during post-natal development. Anat. Embryol. 189, 521-530.
Tran, N., G. Servos, and S. G. Haider, 2006: Ultrastructure of cell contacts of fetal and adult Leydig cells in the rat: a systematic study from birth to senium. Anat. Embryol. 211, 273-282.

Tung, P. S., and I. B. Fritz, 1990: Characterization of rat testicular peritubular smooth muscle cells in culture: alphasmooth muscle isoactin is a specific differentiation marker. Biol. Reprod. 42, 351-365.

Van Nassauw, L., F. Harrisson, and M. Callebaut, 1993: Smooth muscle cells in the peritubular tissue of the quail testis. Eur. J. Morphol. 31, 60-64.

Virtanen, I., M. Kallajoki, O. Narvanen, J. Paranko, L. E. Thornell, M. Miettinen, and V. P. Lehto, 1986: Peritubular myoid cells of human and rat testis are smooth muscle cells that contain desmin type intermediate filaments. Anat. Rec. $215,10-20$.

Wang, N., and D. Stamenovic, 2002: Mechanics of vimentin intermediate filaments. J. Mus. Res. Cell Motil. 23, 535-540.

Welsh, M., R. M. Sharpe, L. Moffat, N. Atanassova, P. T. K. Saunders, S. Kilter, A. Bergh, and L. B. Smith, 2010: Androgen action via testicular arteriole smooth muscle cells is important for Leydig cell function, vasomotion and testicular fluid dynamics. PLoS One 5, e13632.

Wrobel, K.-H., S. Dostal, and M. Schimmel, 1988: Post-natal development of the tubular lamina propria and the intertubular tissue in the bovine testis. Cell Tiss. Res. 252, 639-653.

Wrobel, K.-H., D. Bickel, and R. Kujat, 1995: Distribution pattern of F-actin, vimentin and alpha-tubulin in the bovine testis during post-natal development. Acta Anat. 153, 263-272.

Xie, Q., S. Mackay, S. L. Ullmann, D. P. Gilmore, and A. P. Payne, 1996: Testis development in the opossum Monodelphis domestica. J. Anat. 189, 393-406. 